\title{
Myocardial infarction in monozygotic twins
}

\author{
Arthur Clement (1) , ${ }^{1}$ Fabien Picard, ${ }^{1,2}$ Olivier Varenne ${ }^{1,2}$
}

${ }^{1}$ Cardiology, Cochin Hospital, Assistance Publique - Hôpitaux de Paris, Paris, France

${ }^{2}$ Université de Paris, Paris, France

\section{Correspondence to}

Dr Fabien Picard:

fabien.picard@aphp.fr

Accepted 13 August 2020

\section{DESCRIPTION}

A 46-year-old man presented to the hospital with a brutal chest oppression with mandibular and left arm discomfort. He was a current smoker (28 pack-year) and his father had experienced a myocardial infarction. He was not receiving any medical treatment. The first ECG showed an inferior ST-elevation myocardial infarction (STEMI). Angiography revealed a mid-right coronary artery occluded by a thrombus (figure 1A), treated by angioplasty. He had an uneventful evolution after angioplasty in the coronary care unit and a normal left ventricular ejection fraction. His body mass index (BMI) was $26.6 \mathrm{~kg} / \mathrm{m}^{2}$, his low-density lipoprotein cholesterol (LDL-C) level was $121 \mathrm{mg} / \mathrm{dL}$ and triglyceride level was $233 \mathrm{mg} / \mathrm{dL}$. No other risk factors were identified.

One year and 4 months later, his monozygotic twin brother was admitted to the hospital due to a sudden onset of chest pain and dyspnea. He was a former smoker (25 pack-year) taking aspirin and atorvastatin $10 \mathrm{mg}$ since his brother's infarction. The prehospital ECG showed an inferior STEMI. Coronary angiography disclosed mid-right coronary subocclusion and images suggestive of intracoronary thrombus (figure 1B). Angioplasty was performed with a drugeluting stent implantation in the mid-right coronary artery, followed by resolution of electrocardiographic signs and symptoms. His BMI was $25.2 \mathrm{~kg} / \mathrm{m}^{2}$, LDL-C level was $51 \mathrm{mg} / \mathrm{dL}$ and triglyceride level was $260 \mathrm{mg} /$

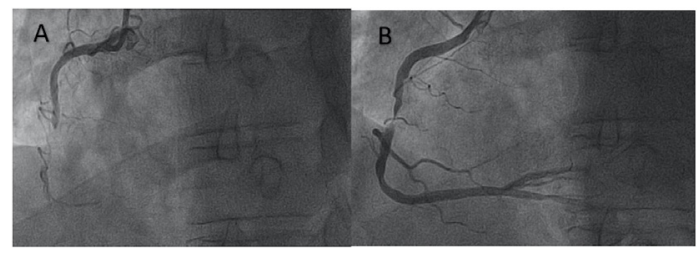

Figure 1 Coronary angiogram of inferior myocardial infarction showing mid-right coronary artery occlusion for the first twin (A) and a subocclusion at the same site for the second twin (B).

\section{Learning points}

- There is a high concordance in coronary anatomy between monozygotic twins, between evident genetic factors and close environmental data.

- It reinforces the importance of primary prevention and thorough screening in twins' siblings, when one is suspected of coronary disease.

dL under atorvastatin. Lipoprotein (a) level was 124 $\mathrm{mg} / \mathrm{dL}$. No other risk factors were identified.

Both twin patients exhibited a very similar coronary artery disease, at the same age, with a very close coronary anatomy and an acute unstable coronary lesion in the mid-right coronary artery. This highlights a high concordance in coronary anatomy between monozygotic twins, between evident genetic factors and close environmental data. ${ }^{12}$

Contributors AC drafted the manuscript and took care of the patient. FP drafted and revised the manuscript and took care of the patient. OV drafted and revised the manuscript and took care of the patient.

Funding The authors have not declared a specific grant for this research from any funding agency in the public, commercial or not-for-profit sectors.

Competing interests None declared.

Patient consent for publication Obtained.

Provenance and peer review Not commissioned; externally peer reviewed.

\section{ORCID iD}

Arthur Clement http://orcid.org/0000-0003-1464-036X

\section{REFERENCES}

1 Marenberg ME, Risch N, Berkman LF, et al. Genetic susceptibility to death from coronary heart disease in a study of twins. N Eng/ J Med 1994:330:1041-6.

2 Frings AM, Mayer B, Böcker W, et al. Comparative coronary anatomy in six twin pairs with coronary artery disease. Heart 2000;83:47-50.
Copyright 2020 BMJ Publishing Group. All rights reserved. For permission to reuse any of this content visit

https://www.bmj.com/company/products-services/rights-and-licensing/permissions/

BMJ Case Report Fellows may re-use this article for personal use and teaching without any further permission.

Become a Fellow of BMJ Case Reports today and you can:

- Submit as many cases as you like

- Enjoy fast sympathetic peer review and rapid publication of accepted articles

- Access all the published articles

- Re-use any of the published material for personal use and teaching without further permission

Customer Service

If you have any further queries about your subscription, please contact our customer services team on +44 (0) 2071111105 or via email at support@bmj.com.

Visit casereports.bmj.com for more articles like this and to become a Fellow 